\title{
Composition and Abundance of Benthic Macro- invertebrates in Freshwater Earthen Ponds of Noakhali District, Bangladesh
}

\author{
Sakalin Chakma ${ }^{1}$, Md. Mofizur Rahman ${ }^{1,}$, , Masuma Akter ${ }^{2}$ \\ ${ }^{1}$ Department of Fisheries and Marine Science, Noakhali Science and Technology University, Sonapur, Noakhali, Bangladesh \\ ${ }^{2}$ Department of Fisheries, University of Dhaka, Dhaka, Bangladesh
}

Email address:

ripondu31184@yahoo.com (Md. M. Rahman)

\section{To cite this article:}

Sakalin Chakma, Md. Mofizur Rahman, Masuma Akter. Composition and Abundance of Benthic Macro-invertebrates in Freshwater Earthen Ponds of Noakhali District, Bangladesh. American Journal of Bioscience and Bioengineering. Vol. 3, No. 5, 2015, pp. 50-56.

doi: $10.11648 /$ j.bio.20150305.15

\begin{abstract}
The composition and abundance of benthic macro-invertebrates in freshwater fish ponds of Noakhali region were analyzed for a period of six month (December-May, 2012). Experimental ponds were categorized as culture, household and derelict and samples were drawn every week during the entire study period using an Eckman grab with dimension of $15.2 \times 15.2 \times 15.2 \mathrm{~cm}$. A total of 10 major groups/taxa were identified viz.; Polychaetes, Oligochaetes, Gastropods, Amphipods, Bivalve, Diptera, Crab, Isopods, Prawn larvae and Copepod. Total macro-benthos abundance was recorded 1555.54, 1466.66 and 2177.79 ind. $/ \mathrm{m}^{2}$ respectively in culture, household and derelict ponds. Oligochaetes were found dominant (49-75\%) in all the experimental ponds. Density of Oligochaetes was recorded $888.89,1088.89$ and $1066.67 \mathrm{ind} . / \mathrm{m}^{2}$ respectively in culture, household and derelict ponds. The overall composition of macro-benthos was Polychaetes $(9.19 \%)$, Oligochaetes (58.56\%), Gastropods (19.23\%), Amphipods (3.85\%), Bivalvia (1.50\%), Diptera (1\%), Crab (0.43\%), Isopods $(0.43 \%)$, Prawn larvae $(0.21 \%)$ and Copepods $(0.85 \%)$. The present study reveals that macrobenthic fauna and their density are variable among the freshwater ponds. The obtained information can be used for further analysis of seasonal variation of macrobenthos, conserve biodiversity and seasonal change of water quality parameter of freshwater ponds.
\end{abstract}

Keywords: Benthic Macro-invertebrates, Composition, Abundance, Freshwater Ponds, Noakhali District

\section{Introduction}

Benthic macro fauna are those organisms that live on or inside the deposit at the bottom of a water body [1-3]. Large benthic animals (those readily visible without the use of a microscope) are collectively referred to as macro-zoobenthos or macro-invertebrates. They are an important and integral component of all aquatic ecosystems [4]. These organisms also play a vital role in the circulation and recirculation of nutrients in aquatic environments. They constitute the link between the unavailable nutrients in detritus and useful protein materials in fish $[5,6]$. Most benthic organisms feed on debris that settle on the bottom of the water and in turn serve as food for a wide range of fishes $[3,5-8]$.

Noakhali is one of the southern coastal districts of Bangladesh. There are thousands of small and larger ponds available in Noakhali region where extensive fish culture is mainly practiced depending on natural food i.e. benthos. In lentic freshwaters, the benthic invertebrates play an essential role in key ecosystem processes, such as food chain dynamics, productivity, nutrient cycling and decomposition [9]. Benthos can give us reliable information on stream, lake and ponds' water quality. Because of their abundance and position as "middlemen" in the aquatic food chain, benthos plays a critical role in the natural flow of energy and nutrients. Therefore, it is essential to maintain the nutrient enrichment in fish ponds which will in turn increase the fish production.

A lot of studies have been performed on coastal macrobanthos of Bangladesh [10-16]. However, studies on benthic macro invertebrates in freshwater ponds of Noakhali district, Bangladesh are scanty. Despite the importance of benthic macro invertebrate in the aquatic environment, particularly in the freshwater fish ponds, information on the species composition and abundance of benthic macro invertebrate in Noakhali district of Bangladesh is still lacking. 
Therefore, this study is an attempt to trace the required information needed in this regard.

\section{Materials and Methods}

\subsection{Study Area}

The experimental work was conducted at various types of earthen fish ponds of Noakhali district, Bangladesh. Noakhali is a South-Eastern district of Bangladesh located in Chittagong division. The district lies between $22^{\circ} 07^{\prime}$ and $23^{\circ} 08^{\prime}$ north latitudes and between $90^{\circ} 53^{\prime}$ and $91^{\circ} 27^{\prime}$ east longitudes. Total no. of ponds in Noakhali region is 79,167 with an area of 27,238 acre (Fig. 1) [17].

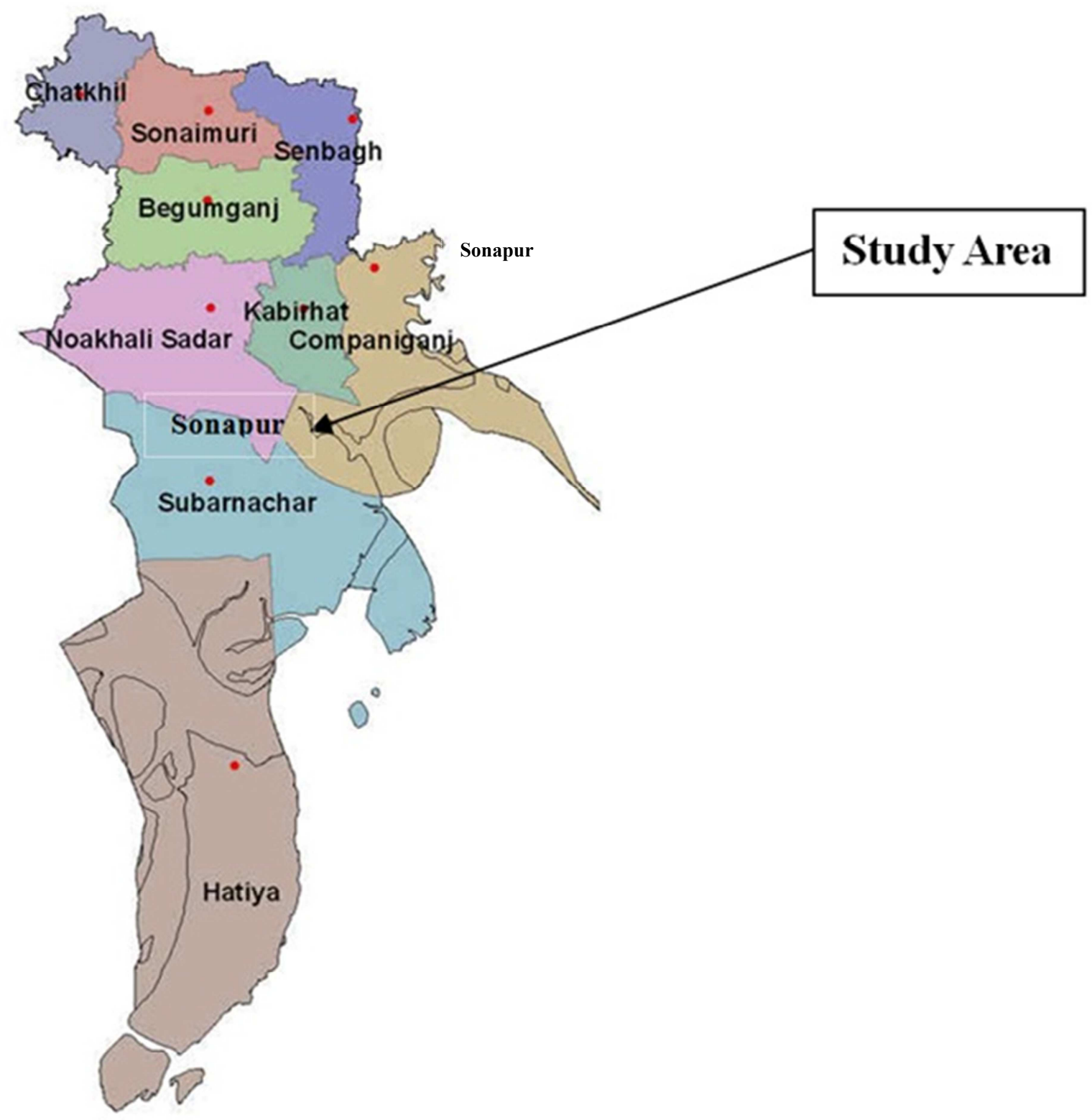

Figure 1. Map showing the location of research station.

\subsection{Sampling Site}

A total of 9 working stations were selected to conduct the research. Three types of ponds were selected for accomplishing the experiment viz.; culture, household and derelict ponds. Sampling was carried out during pre-monsoon (December-May, 2012). Samples were collected every week during the entire study period in triplicate from each type of pond using an Eckman grab (Product of Netherland) with dimension of $15.2 \times 15.2 \times 15.2 \mathrm{~cm}$.

\subsection{Sample Preparation}

The sampler was pushed into the sediment and sediment of the corer was taken into a labeled polyethylene bag. The sediment samples were transferred from the polyethylene bag to a bucket and mixed with water. Then the mixed water passed through a $0.5 \mathrm{~mm}$ mesh sized hand-sieve to remove 
the waste particles and the separated macro-benthos with other residue were preserved in labeled plastic container with $10 \%$ buffered formalin and transferred to laboratory for further analysis.

\subsection{Sample Analysis}

In the laboratory, 1 gm "Rose Bengal" was mixed with 100 $\mathrm{ml}$ water and the prepared solution was added in every container where organisms were preserved in formalin to increase the visibility of organisms. For identification, the samples were taken into a round transparent Petri dish (diameter $15 \mathrm{~cm}$ and depth $2 \mathrm{~cm}$ ) and placed on a white tissue paper for the easy contrast of vision. Organisms were sorted and enumerated under major taxa and preserved in small vials by using small brush or forceps. Binocular microscope with digital camera (Model No: XSZ21-05DN) was used to identify and capture the image of benthos. An attempt has been made to identify the benthic macro invertebrates up to genus or species level but failed due to time limitation, lack of fund and appropriate literature.

\subsection{Statistical Analysis}

The statistical analysis of different macrobenthic parameters was carried out by one-way ANOVA using the statistical package of Statgraphics Version 7 while the Microsoft Excel 2007 was used to plot graphs for dissemination of the results.

\section{Results}

A total of 10 taxa/major groups viz.; Polychaetes, Oligochaetes, Gastropods, Amphipods, Bivalve, Diptera, Crab, Isopods, Prawn larvae and Copepod were identified in the experimental ponds. Oligochaetes and Gastropods were observed among all the experimental ponds. Total macrobenthos abundance was recorded 1555.54, 1466.66 and 2177.79 ind. $/ \mathrm{m}^{2}$ respectively in culture, household and derelict ponds. Among the identified taxa, Oligochaetes were found dominant $(49-75 \%)$ in all the experimental ponds. Density of Oligochaetes recorded 888.89, 1088.89 and 1077.67 ind. $/ \mathrm{m}^{2}$ respectively in culture, household and derelict ponds. The highest number of taxa (8) was recorded in culture ponds while the lowest number (4) was found in derelict ponds. 6 groups of benthic macro-invertebrates were recorded in household ponds (Table 1). The overall compositions of macrobenthos were Polychaetes (9.19\%), Oligochaetes (58.56\%), Gastropods (19.23\%), Amphipods (3.85\%), Bivalvia (1.50\%), Diptera (1\%), Crab (0.43\%), Isopods $(0.43 \%)$, Prawn larvae $(0.21 \%)$ and Copepods $(0.85 \%)$. Percentage composition of the identified macrobenthic groups in the studied ponds were also found variable. In culture pond, percentage of Oligichaetes, Polechaetes, Gastropods, Amphipods, Diptera, Isopods, Crab and Prawn larvae were $57 \%, 31 \%, 1 \%, 4 \%, 4 \%, 1 \%, 1 \%$ and $1 \%$ respectively. In household pond, percentage compositions of macrobenthic groups were $74 \%$ (Oligichaetes), $7 \%$
(Gastropods), 9\% (Amphipods), 1\% (Crab), 3\% (Copepod) and $6 \%$ (Unidentified). And in derelict pond, Oligichaetes, Gastropods, Bivalvia and Unidentified groups were found $49 \%, 40 \%, 4 \%$ and $7 \%$ respectively (Fig. 3, 4, 5 \& 6). Moreover, distribution scenario of the identified macrobenthos in various types of ponds was also represented in below.

\section{Oligochaeta:}

Olygochaetes were found common among all the studied ponds and ranked in $1^{\text {st }}$ position as regards abundance of total macrobenthos $(58.55 \%)$. The maximum value (1088.89 ind. $/ \mathrm{m}^{2}$ ) was recorded at household ponds while lowest $(888.89$ ind. $/ \mathrm{m}^{2}$ ) was in culture ponds (Table 1; Fig. 3 ).

Gastropoda:

Gastropods were also observed the leading group ranked in $2^{\text {nd }}$ position contributing $19.23 \%$ of total benthic macroinvertebrates. Gastropods had its highest density (877.78 ind. $\left./ \mathrm{m}^{2}\right)$ at derelict ponds and lowest $\left(22.22 \mathrm{ind} . / \mathrm{m}^{2}\right)$ in culture ponds (Table 1; Fig. 3).

Polychaeta:

Among the three types of pond, Polychaetes were found only in culture pond with an average density of 477.78 ind. $/ \mathrm{m}^{2}$. They ranked $3^{\text {rd }}$ and constituted $9.19 \%$ of total macrobenthos (Table 1; Fig. 3).

Amphipoda:

Amphipods ranked in $5^{\text {th }}$ position with contributing $3.85 \%$ of total macro-benthos. It was observed in culture and household ponds with a density of 66.65 ind. $/ \mathrm{m}^{2}$ and 133.33 ind. $/ \mathrm{m}^{2}$ respectively while absent in derelict ponds (Table1; Fig. 3).

Bivalvia:

Bivalvia were found only in derelict ponds with an abundance of 77.78 ind. $/ \mathrm{m}^{2}$. It ranked $6^{\text {th }}$ position contributing $1.50 \%$ of total macro-benthos (Table 1; Fig. 3).

Diptera:

Diptera contributed $1.07 \%$ of total macro-benthos and ranked $7^{\text {th }}$ position. It was found only in culture pond with the quantity of $44.44 \mathrm{ind} . / \mathrm{m}^{2}$ while absent in household and derelict ponds (Table 1; Fig. 3).

Copepoda:

They constituted $3.79 \%$ of total macro-benthos (Table 1) and ranked $8^{\text {th }}$ position. It was observed only in household ponds with a value of 44.44 ind. $/ \mathrm{m}^{2}$ (Table 1; Fig. 3).

Prawn Larvae:

It comprised $0.21 \%$ of total macro-benthos and ranked $10^{\text {th }}$. It was found only in culture ponds with the quantity of 11.11 ind. $/ \mathrm{m}^{2}$ while totally absent in derelict ponds (Table 1 ; Fig. 3).

Crab:

Crab was recorded at culture and household ponds. They constituted $0.43 \%$ of total macrobenthos and ranked $9^{\text {th }}$. Maximum value (11.11 ind. $/ \mathrm{m}^{2}$ ) was found at culture ponds (Table 1; Fig. 3).

Isopods:

They represented $0.43 \%$ of total macrobenthos and ranked $9^{\text {th }}$. It was found only in culture pond with an abundance of 22.22 ind. $/ \mathrm{m}^{2}$ (Table 1; Fig. 3). 

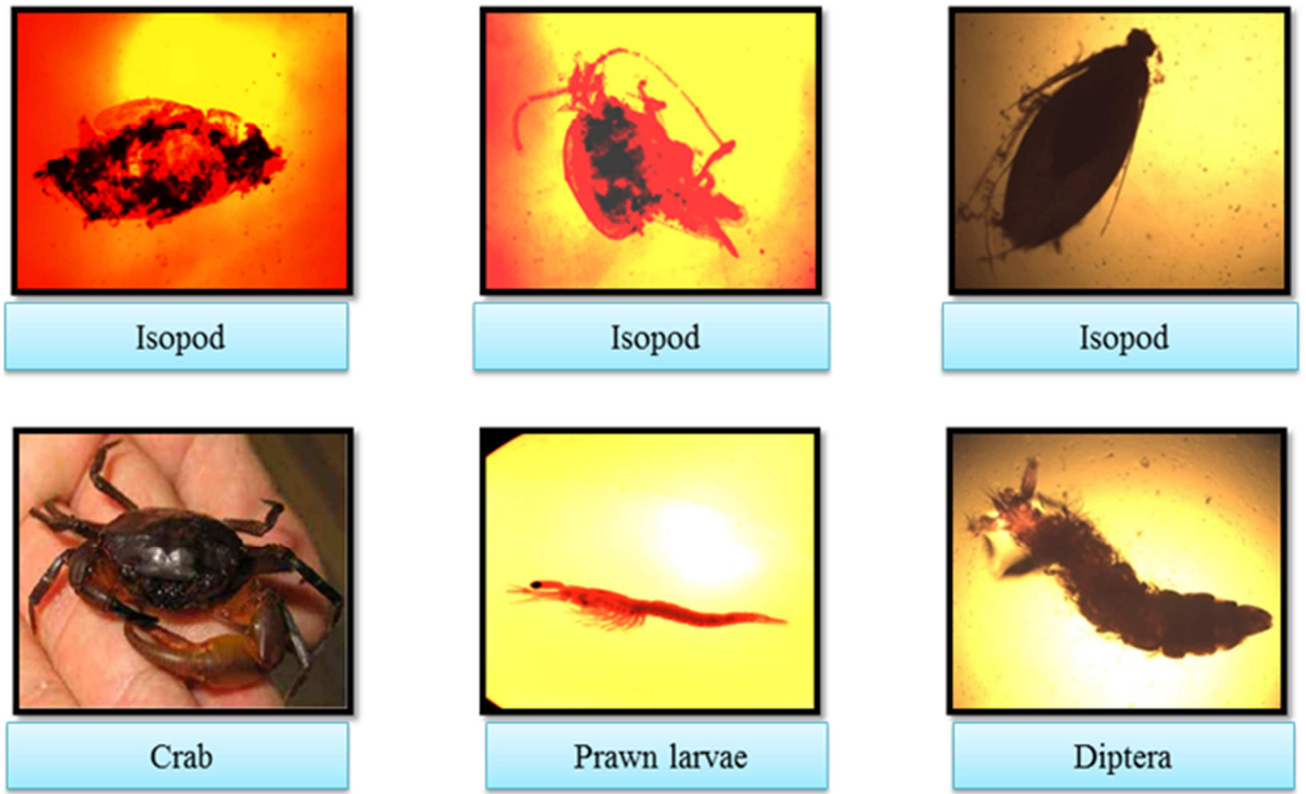

Prawn larvae

Diptera
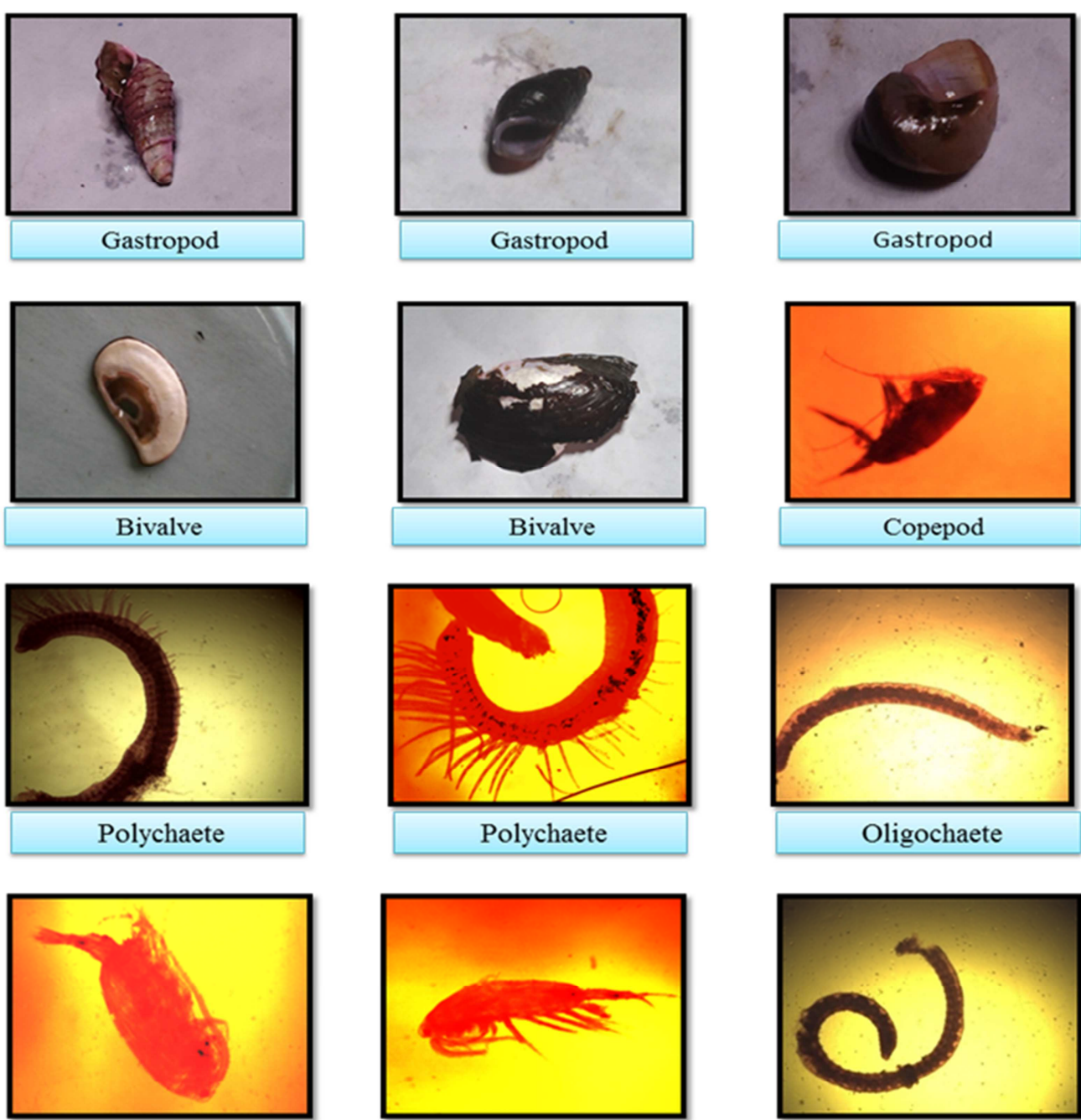

Amphipod

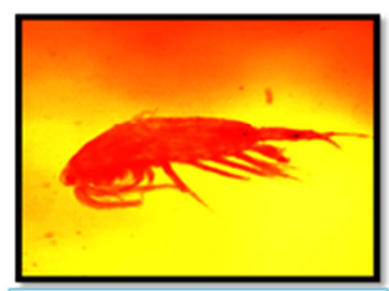

Amphipod

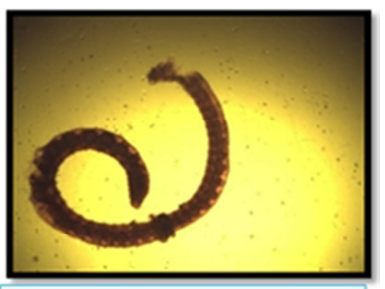

Oligochaete

Figure 2. The macrobenthic organisms identified during the study period 


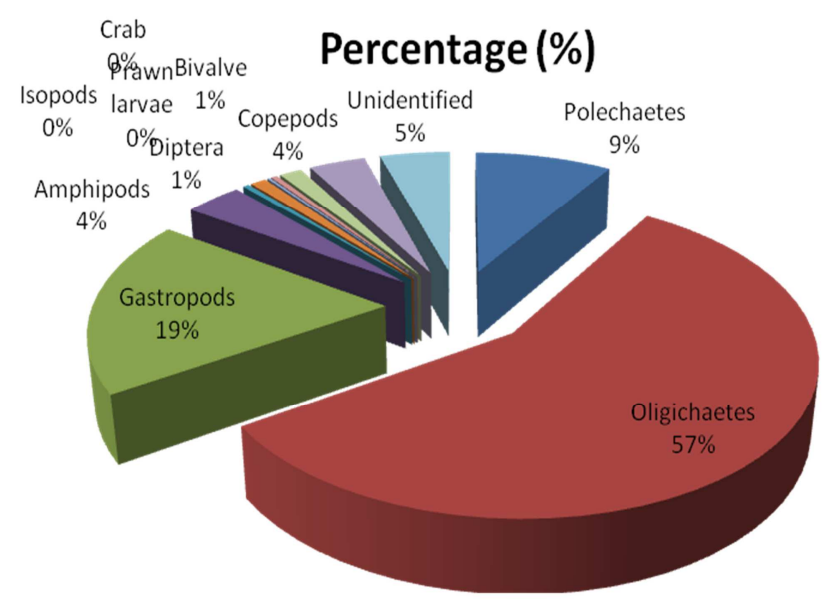

Figure 3. Percentage composition of macro-benthos in the study area.

\section{Percentage (\%) of Macrobenthos in Culture ponds}

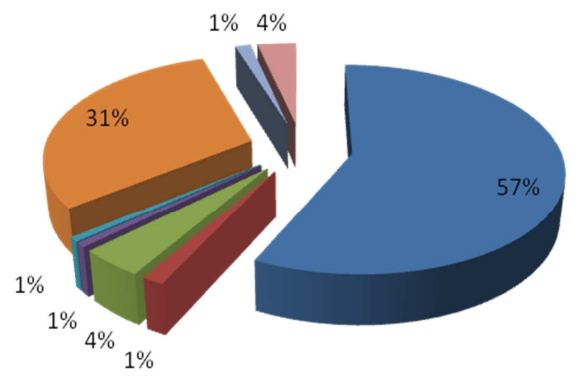

\section{Percentage (\%) of Macrobenthos in Household ponds}

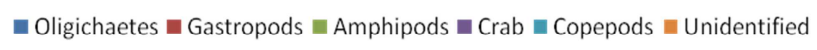

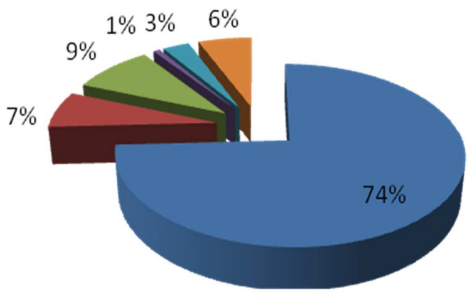

Figure 5. Percentage composition of macro-benthos at household ponds.

\section{Percentage (\%) of Macrobenthos in Derelict ponds}
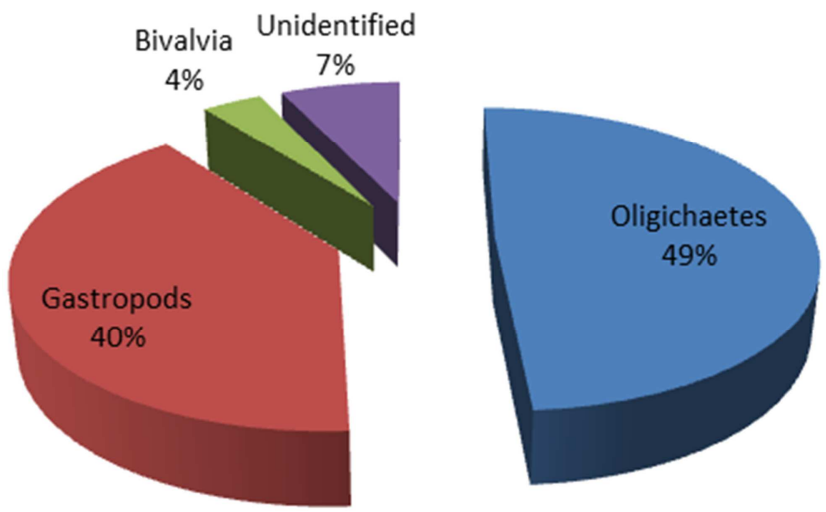

Figure 6. Percentage composition of macro-benthos at derelict pond.

Figure 4. Percentage composition of macro-benthos at culture ponds.

Table 1. Identified macro-benthos and their density among the experimental ponds.

\begin{tabular}{|c|c|c|c|c|c|c|}
\hline Groups & $\begin{array}{l}\text { Culture pond } \\
\text { Mean value (Ind. } / \mathbf{m}^{2} \text { ) }\end{array}$ & $\begin{array}{l}\text { Household pond } \\
\text { Mean value (Ind. } / \mathbf{m}^{2} \text { ) }\end{array}$ & $\begin{array}{l}\text { Derelict pond } \\
\text { Mean value (Ind. / m²) }\end{array}$ & $\begin{array}{l}\text { Total } \\
\text { (Ind. } / \mathbf{m}^{2} \text { ) }\end{array}$ & Percentage (\%) & $\begin{array}{l}\text { Rank of } \\
\text { Abundance }\end{array}$ \\
\hline Oligichaetes & 888.89 & 1088.89 & 1066.67 & 3044.45 & 58.55 & 1 \\
\hline Gastropods & 22.22 & 100 & 877.78 & 1000.00 & 19.23 & 2 \\
\hline Polychaetes & 477.78 & - & - & 477.78 & 9.19 & 3 \\
\hline Amphipods & 66.65 & 133.33 & - & 199.98 & 3.85 & 5 \\
\hline Bivalvia & - & - & 77.78 & 77.78 & 1.50 & 6 \\
\hline Diptera & 55.56 & - & - & 55.56 & 1.07 & 7 \\
\hline Copepods & - & 44.44 & - & 44.44 & 0.85 & 8 \\
\hline Isopods & 22.22 & - & - & 22.22 & 0.43 & 9 \\
\hline Crab & 11.11 & 11.11 & - & 22.22 & 0.43 & 9 \\
\hline Prawn larvae & 11.11 & - & - & 11.11 & 0.21 & 10 \\
\hline Unidentified & - & 88.89 & 155.56 & 244.45 & 4.7 & 4 \\
\hline Total Taxa & 8 & 6 & 4 & & & \\
\hline Total (Ind. $/ \mathrm{m}^{2}$ ) & $1555.54(29.91 \%)$ & $1466.66(28.21 \%)$ & $2177.79(41.88 \%)$ & 5199.99 & 100.00 & \\
\hline
\end{tabular}

\section{Discussion}

The macrobenthic fauna is important for enhancing of aquatic resources and also play an important role in food chain and biological purification of water [18]. Abiotic and biotic factors of freshwater environment probably affect the composition and abundance of macrobenthos. Biotic factors were competition for space and food, predation, reproduction, substrate settlement preference and the abiotic factors were temperature, air and light exposure, dissolved $\mathrm{O}_{2}$ and natural disasters [19, 20].

Composition, distribution and abundance of macrobenthic fauna of freshwater environment have been studied by many researchers. Our findings are more or less comparable to others. The taxa/groups which were identified in the present study are in line with the findings of Biswas, 2015 and Asadujjaman et al. 2010 [12, 21]. Biswas, 2015 recorded 8 major groups viz.; Oligiochaeta, Hirudinea, Crustacea, Odonata, Coleptera, Diptera, Gastrpoda and Bivalvia in a 
rural pond near Naihati, West Bengal, India while Asadujjaman et al. 2010 recorded 10 major groups named Polychaetes, Oligochaetes, Shrimp larvae, Crab, Gastropods, Isopods, Bivalves, Copepods, Annelids, Amphipods and others from Hatiya and Nijhum Dweep islands, Bangladesh $[12,21]$. However, higher number of benthic groups than the current study has also been confirmed by Hossain, 2009 who recorded 20 taxa of macro-zoo-benthos of Meghna River estuary of which Oligochaetes, Polychaetes and Mesogastropods were dominant [16]. Moreover, lower number of macrobenthic groups than the current research was also reported by Nupur et al. 2013; Khan et al. 2007; Ahmed et al. 1991 and Sharma et al. 2015 [11, 22-24]. Nupur et al. 2013 found 4 major groups of macrobenthos named Chironomidae, Oligochaeta, Mollusca and Ceratoponogonidae in aquaculture ponds whereas Khan et. al. 2007 recorded 5 major groups of macrobenthos named Oligochaeta, Polychaeta, Insecta, Bivalvia and Gastropoda in Mouri River of Khulna [22, 11].

Variable percentage composition of macrobenthos in freshwater environment was also reported by many researchers. Ahmed et al. 1991 found 5 major groups of macrobenthic fauna of Kaptai Lake, Bangladesh with a composition of $44.60 \%$ (Chironomid larvae), $36.62 \%$ (Oligochactes), 12.21\% (Pclecypods), 4.33\% (Gastropod) and $2.16 \%$ (Culicid) while Sharma et al. 2015 recorded 3 major groups of macrobenthic invertebrates in two perennial ponds of Jammu region, India with a percentage of $15.38 \%$ (Annelida), 61.54\% (Arthropoda), 23.8\% (Mollusca) in pond-1 and 37.5\% (Annelida), 50\% (Arthropoda), 12.5\% (Mollusca) in pond-2 [23, 24].

Differences in abundance of macrobenthic organisms among the experimental ponds were probably related to the habitat and environmental condition of the studied ponds. The variation also may be due to management strategy of the experimental ponds. Culture ponds were well managed for fish culture whereas household or derelict ponds were little or no managed. Fertilizer and artificial foods were applied in culture pond for successful fish production whereas various types of anthropogenic activities like washing, bathing of the man and cattle, defecation, agricultural runoff were performed in household and derelict ponds which in turn increase the organic load of the pond water. This leads to detrimental effects like eutrophication, algal bloom, depletion of dissolved oxygen etc.. Under such condition of pollution, indicator species are known to thrive.

Derelict pond was dominated by the macrobenthic groups of Oligochaetes, Gastropods and Bivalves and maximum abundance (2178) was recorded than the culture and household pond. The dominance of these groups may be due to suitable ecological condition such as high level of organic matter in the bottom soil of the pond. The variation among the stations could also probably be due to higher input of nutrients from the sediments. Generally, relatively soft surface and high detritus or organic matter may cause for high food diversity hence supports greater abundance of benthic organisms [25-26, 23]. The abundance of
Oligochaeta and Mollusca was recorded 1200 and 977 ind. $/ \mathrm{m}^{2}$ respectively in aquaculture ponds by Nupur et al. 2013 which is similar to our findings [22]. Khan et al. 2007 recorded 1040 ind. $/ \mathrm{m}^{2}$ of macrobenthos in Mouri River of Khulna, Bangladesh which is lower than the current study [11]. However, higher abundance of macrobenthos than the present study was also been confirmed by Asadujjaman et al. 2010 who found maximum density (4511 ind. $/ \mathrm{m}^{2}$ ) in Hatiya and Nijhum Dweep Islands, Bangladesh [12].

\section{Conclusions}

The present study reveals that macrobenthic fauna and their density are variable among the freshwater ponds. The obtained information can be used for further analysis of seasonal variation of macro-benthos, conserve biodiversity and seasonal change of water quality parameters of freshwater ponds. The record of various pollution indicators in freshwater ponds also infers the dark future of the ponds if no effective measures are taken. Therefore, awareness among local people, effective co-ordination among management authority, removal of algal blooms, addition of freshwater and regular dredging of sediments are essential for present and future management of these ponds.

\section{Acknowledgements}

The authors wish to acknowledge the Chairman of Department of Fisheries and Marine Science, Noakhali Science and Technology University, Bangladesh for providing the facilities to undertake this study. The authors also wish to thank the owner of the ponds for giving the permission of sampling to their ponds.

\section{References}

[1] Odum. EP. Fundamentals of ecology, 3rd W.B. Saunders Company. Philadelphia, 1971; pp: 574.

[2] Barnes, R. D. and Hughes, S. 1988: An introduction to marine ecology. 2nd Edn., Blackwell Scientific Publications, UK., pp: 351.

[3] Idowu, E. O. and Ugwumba, A. A. A. Physical, chemical and benthic faunal characteristics of a Southern Nigeria Reservoir. The Zoologist, 2005; 3: 15-25

[4] Hossain, M. B. Macrobenthos Community Structure of a Tropical Estuary. LAP Publishing Company, Germany, 2011; pp: 84.

[5] Imevbore, AM and Bakare, O Ed. Studies, 1970, 7, 87-98.

[6] Adebisi, A. A. A Report Prepared for Agro Team. Ibadan, Nigeria, 1989; pp: 7-8.

[7] Ajao, E. A. and Fagade, S. O. The benthic macro-infauna of Lagos Lagoon. The Zoologist, 2002; 1(2): 1-5.

[8] Oke, O. O. Limnology and macrobenthos of Owena reservoir. M.Phil. Thesis, Universityof Ibadan, Ibadan, Nigeria. 1990; pp: 96. 
[9] Covich, A. P., Margaret, A. P. and Todd, A. C. The Role of Benthic Invertebrate Species in Freshwater Ecosystems: Zoobenthic species influence energy flows and nutrient cycling. Bio Sci., 1999; 49(2):119-127.

[10] Belaluzzaman, A. M. Ecology of the intertidal macro-benthic fauna in Cox's Bazar Coastal area, Bangladesh. M.Sc. Thesis, IMS, University of Chittagong, Bangladesh, 1995; pp: 55.

[11] Khan, A. N., Kamal, D., Mahmud, M. M., Rahman, M. A. and Hossain, M. A. Diversity, Distribution and Abundance of Benthos in Mouri River, Khulna, Bangladesh, Int. J.Sustain. Crop Prod, 2007; 2(5): 19-23.

[12] Asadujjaman, M., Hossain, M. B., Shamsuddin, M., Amin, M. A. and Azam, A. K. M. Occurrence and abundance of macrobenthos of Hatiya and Nijhum Dweep Islands, Bangladesh. Middle-East J. Sci. Res., 2012; 11: 184-188.

[13] Mahmood, N., Zafar, M., Barua, P. K. and Ali, S. Macrobenthic fauna of an aquaculture pond of Chkaria Sundarban. Pak. J. Sci. Ind. Res., 1993; 36: 156-158.

[14] Rao, G. S. and Sharma, D. V. R. Meio-benthos of the Gosthani estuary, Int. J. Mar. Sci.,1990; 19: 171-173.

[15] Hossain, M. B. A preliminary study on intertidal macrobenthos of Chittagong coast in Bangladesh, Int. J. Ani. Fish. Sci., 2008; 2(2): 170-175.

[16] Hossain, M. B. Macro-zoo-benthos of the Meghna River estuarine bed with special reference to Polychaete faunal biodiversity, Int. J. Sustain. Ag. Tech., 2009; 5(3): 11-16.

[17] BBS. Bangladesh Bureau of Statistics, Noakhali. Statistical Year book of Bangladesh. $33^{\text {rd }}$ Edn. Planning Division, Ministry of Planning, Bangladesh. 2011; pp: 3.

[18] Quasin, S., Ganguly, K., Roy, S. and Nath, A. Diversity of macrobenthic fauna of two pisciculture ponds of West Bengal. Envirn. Ecol., 2009; 27: 1017-1021.

[19] Ramamurthy, S. Hydrobiological studies in the Madras coastal water. J. Madras Univ., 1953; 13(23): 148-163.

[20] Weyl and Peter, K. Oceanography-An Introduction to the Marine Environment: Mostly physical, chemical and geological with some biology and ecology. Prentice-hall, New York, 1970, pp: 535.

[21] Biswas, D. M. Macrozoobenthic diversity of a rural pond near Naihati, West Bengal. Int. R. J. Interdisciplinary \& Multidisciplinary Stud., 2015; 1(4):11-14.

[22] Nupur, N., Shahjahan, M., Rahman, M. S. and Fatema, M.K. Abundance of macrobenthos in relation to bottom soil textural types and water depth in aquaculture ponds. Int. J. Agril. Res. Innov. \& Tech., 2013;3 (2): 1-6.

[23] Ahmed, K. K., Haldar, G. C., Hossain, M. M. and Paul, S. K. Macrobenthic fauna of Kaptai Lake (Bangladesh). Ind. J. Fish., 1991; 38(3):173-176.

[24] Sharma, K. K., Kour, S. and Antal, N. Diversity of Zooplankton and Macrobenthic invertebrates of two Perennial Ponds in Jammu region. J. Glob. Biosci., 2015; 4(2):13821392.

[25] Arshad, A., Ara, R., Amin, S. M. N., Effendi, M., Zaidi, C. C. and Mazlan, A. G. Influence of environmental parameters on shrimp post-larvae in the Sungai Pulai sea grass beds of Johor Strait, Peninsular Malaysia. Sci. Res. Essays, 2011; 6: 55015506.

[26] Aura, C. M., Raburu, P. O. and Herrmann, J. Macro invertebrates' community structure In Rivers Kipkaren and Sosiani, River Nzoia basin, Kenya. J. Eco. Nat. Environ., 2011; 3: 39-46. 